\title{
$\mathrm{C}_{\mathrm{BP}}$
}

\section{Evaluation of pulmonary function and respiratory symptoms in pyrochlore mine workers}

\author{
Ritta de Cássia Canedo Oliveira Borges ${ }^{1}$, José Cerqueira Barros Júnior ${ }^{2}$, \\ Fabrício Borges Oliveira', Marisa Andrade Brunherotti ${ }^{3}$, \\ Paulo Roberto Veiga Quemelo
}

1. Curso de Fisioterapia, Centro Universitário do Planalto de Araxá UNIARAXÁ - Araxá (MG) Brasil.

2. Companhia de Mineração do Pirocloro de Araxá - COMIPA - Araxá (MG) Brasil.

3. Programa de Pós-Graduação em Promoção de Saúde, Universidade de Franca - UNIFRAN - Franca (SP) Brasil.

Submitted: 10 September 2015. Accepted: 31 May 2016.

Study carried out at the Centro Universitário do Planalto de Araxá UNIARAXÁ - and at the Companhia de Mineração do Pirocloro de Araxá COMIPA - Araxá (MG) Brasil.

\begin{abstract}
Objective: To identify respiratory symptoms and evaluate lung function in mine workers Methods: This was a cross-sectional observational study involving production sector workers of a pyrochlore mining company. The subjects completed the British Medical Research Council questionnaire, which is designed to evaluate respiratory symptoms, occupational exposure factors, and smoking status. In addition, they underwent pulmonary function tests with a portable spirometer. Results: The study involved 147 workers (all male). The mean age was $41.37 \pm 8.71$ years, and the mean duration of occupational exposure was $12.26 \pm 7.09$ years. We found that $33(22.44 \%)$ of the workers had respiratory symptoms and that $26(17.69 \%)$ showed abnormalities in the spirometry results. However, we found that the spirometry results did not correlate significantly with the presence of respiratory symptoms or with the duration of occupational exposure. Conclusions: The frequencies of respiratory symptoms and spirometric changes were low when compared with those reported in other studies involving occupational exposure to dust. No significant associations were observed between respiratory symptoms and spirometry results.
\end{abstract}

Keywords: Spirometry; Mining; Niobium; Occupational exposure.

\section{INTRODUCTION}

Mining has historically been associated with health problems caused by occupational and environmental exposure to mine waste, particularly in developing countries. (1) Occupational and environmental pollution in the form of dusts, fumes, vapors, and toxic gases are risk factors for respiratory disorders. ${ }^{(2)}$ The prevalence and severity of mining-related occupational lung diseases are a function of the commodities mined, the duration of occupational exposure, and the levels of occupational exposure, as well as of concomitant diseases, environmental conditions, and lifestyle. (3) There are few epidemiological data on pneumoconiosis in Brazil, and such data refer to some branches of mining and focal situations. ${ }^{(4)}$ Exposure to mineral dust is known to be one of the precipitating causes for the development of pneumoconiosis, although there are other factors that may participate in its pathogenesis. ${ }^{(5)}$ Among the lung diseases that are prominent in miners are silicosis, asbestosis, and coal worker's pneumoconiosis. ${ }^{(6)}$ The average expected time to the onset of pneumoconiosis and its diagnosis is approximately 10 years of working in mining ${ }^{(5)}$; however, depending on the function performed by the worker, the time to disease onset may be less than 5 years. ${ }^{(7)}$ Occupational lung diseases are considered a public health problem that poses potential risks to the country's economy, because the country will have to support a proportion of patients who are unfit to work.
Therefore, the aim of understanding the pathophysiological mechanisms resulting from this type of exposure is to reduce the incidence of these diseases. ${ }^{(6,7)}$

The state of Minas Gerais, Brazil, accounts for $75 \%$ of the entire worldwide production of pyrochlore. The state exports approximately 62,000 tons of ferroniobium (FeNb) annually, and it is estimated that this type of mining can be operated for a further 400 years. ${ }^{(8)}$ Pyrochlore is part of a group of minerals that are of great economic interest, particularly as a source of niobium, ${ }^{(9)}$ having many useful functions and applications in various economic branches, such as the aerospace, armament, and nuclear industries, as well as numerous other applications, such as optical lenses, high intensity lights, and electronic goods. ${ }^{(10)}$ Niobium is considered an inert metal that causes low pulmonary reactivity. ${ }^{(11,12)}$ However, we found no studies focusing on pulmonary function impairment and respiratory symptoms in workers exposed to niobium (pyrochlore).

In view of these facts and because of the paucity of studies of workers exposed to pyrochlore, it is important to assess the effects that exposure to pollutants associated with pyrochlore have on the respiratory symptoms and pulmonary function of such workers, in order to establish parameters for intervention, prevention, and health promotion. In this context, the objective of the present study was to evaluate pulmonary function and identify respiratory symptoms in such miners, as well as to assess correlations among the study variables. 


\section{METHODS}

\section{Study subjects and study site}

This was a cross-sectional observational study involving production sector workers of one of the major open-pit producers of FeNb in the world. In order to produce FeNb, pyrochlore is first mechanically extracted from the ground. Subsequently, the pyrochlore concentrate is transformed into niobium concentrate, which is then mixed with iron oxide and aluminum, originating the final product: FeNb. Particulate matter is measured annually through sample monitoring, being considered respirable low-toxicity dust. It contains no silica or asbestos. The mining company conducts occupational risk assessments annually, in accordance with the Regulatory Guidelines of the Brazilian Ministry of Labor. The assessments are focused on each worker, targeting the environment, safety, and health, and are monitored by legal programs, such as the Occupational Health Medical Control Program, which includes chest X-ray, and the Respiratory Protection Program. The company provides personal protective equipment (PPE) and supervises its use, maintaining strict document control, with a controlled periodicity, and the use of PPE is monitored through ongoing on-site inspections. All workers use a FFP2 valved respirator providing protection against fine particles, fumes, and toxic mists (maximum filter penetration: 6\%), and dust control is accomplished by wetting the site.

On the basis of the total number of workers in the sector studied ( $N=237)$, we used a convenience sample, consisting of 147 workers, corresponding to a margin of error of $5 \%$ and a $95 \%$ confidence interval. The inclusion criteria for participant selection were having a weekly workload $\geq 30$ hours and having worked in mining for at least one year. We excluded subjects with severe cardiovascular disease, those with chronic lung disease and/or experiencing an exacerbation, and those with (rheumatologic, orthopedic, or neurologic) pathological conditions that prevented data collection. The workers evaluated were operational sector employees: machinery operators $(n=69)$; drivers ( $n$ $=53)$; controllers $(n=17)$; samplers $(n=9)$; and employees engaged in the heavy machinery repair and maintenance sector $(n=11)$. These workers could be involved in more than one function (e.g.: machinery operation and driving). Machinery operators and drivers perform activities involving the operation of bulldozers, excavators and rollers; drivers are those who are meant for trucks that hold approximately 12 tons and transport the extracted material to the material delivery points. Controllers are support workers in truck loading logistics and machinery logistics at the working fronts. Samplers are responsible for collecting material for mineralogical sampling. Mechanics perform general repair and maintenance of machinery. The present study was approved by the Research Ethics Committee of the University of Franca (Protocol no. 20973213.0.0000.5495), in accordance with Brazilian National Health Council Resolution 466/12.

\section{Data collection instruments}

Data were collected by means of a questionnaire eliciting sociodemographic, anthropometric, and occupational information. Respiratory symptoms, occupational exposure factors, and smoking status were assessed using the British Medical Research Council questionnaire (MRCQ). This questionnaire addressing respiratory symptoms and occupational exposure to inhaled pollutants is used by the Jorge Duprat Figueiredo Foundation for Occupational Safety and Medicine, located in the city of São Paulo, Brazil. ${ }^{(13)}$ The MRCQ comprises questions on respiratory symptoms (cough, phlegm, wheezing, and dyspnea), history of illness in the past 2 years, and smoking history, as well as a checklist for previous illness. The question responses are dichotomous, and the questionnaire is administered in the workplace, always by the same investigator.

After the questionnaire was administered, pulmonary function was assessed with a hand-held spirometer (Spirobank G; MIR, Rome, Italy), which can make direct graphic recordings, in accordance with the American Thoracic Society criteria. (14) Spirometry technical procedures, as well as acceptability and reproducibility criteria for spirometry, were in accordance with the standards adopted by Brazilian Consensus Guidelines for Spirometry. ${ }^{(15,16)}$ The highest FVC value achieved was selected, and, for $\mathrm{FEV}_{1}$, the highest value obtained from the curves with PEF values within the acceptability criteria was taken into account. ${ }^{(15,16)}$ All measurements were performed by the same investigator.

\section{Data analysis and statistical treatment}

Workers were classified as symptomatic if they presented with at least one of four following respiratory symptoms: cough and phlegm for at least three months a year; wheezing (only when associated with breathlessness); and dyspnea (self-report of being unable to keep pace with another person of the same age, walking on level ground, or self-report of the need to stop and rest when walking on the flat at one's own pace).

Spirometry results were expressed as percentage of predicted. ${ }^{(16)}$ To that end, reference values for FVC and $\mathrm{FEV}_{1}$ were calculated using reference equations for the Brazilian population. ${ }^{(17)}$ Lung disease and severity of disease were classified in accordance with the Brazilian Spirometry Guidelines. ${ }^{(15)}$

Body mass index (BMI) was classified as normal weight (18.5-24.9 kg/m²), overweight (25.0-29.9 $\left.\mathrm{kg} / \mathrm{m}^{2}\right)$, class I obesity $\left(30.0-34.9 \mathrm{~kg} / \mathrm{m}^{2}\right)$, class II obesity (35.0-39.9 kg/m²), and class III obesity ( $\geq$ $\left.40.0 \mathrm{~kg} / \mathrm{m}^{2}\right){ }^{(18)}$

Participants were categorized by smoking status as smokers, former smokers, or nonsmokers, and smoking history was quantified in pack-years. Every worker who reported smoking one or more cigarettes a day for more than one year and who continued smoking at the time of the interview was considered a smoker. Workers who reported quitting smoking more than one year prior were classified as former 
smokers. Workers who had never experimented with cigarettes were considered nonsmokers. Pack-years were calculated by dividing the number of cigarettes smoked per day by 20 and multiplying that value by the number of years smoked. ${ }^{(19)}$

The study population characteristics are given in tables, in which data are expressed as frequencies, proportions, means, standard deviations, and medians. The data were tabulated and analyzed with Microsoft Exce ${ }^{\circledR}$ and GraphPad Prisma, version 6.0 (GraphPad Software, San Diego, CA, USA). Normality was tested with the Kolmogorov-Smirnov test, which revealed that the data were nonparametric in nature. The association between respiratory symptoms and spirometry results was assessed with the chi-square test, and, for contingency tables with at least one expected value of less than 5, we used Fisher's exact test. The correlation between duration of working in mining and spirometric indices was assessed with Spearman's correlation coefficient. For this correlation analysis, the worker data were divided into two sets: (1) workers who had never smoked; and (2) workers who smoked or were former smokers. The level of significance for all statistical tests was set at $5 \%$.

\section{RESULTS}

All participants were males in the 23- to 61-year age group. The mean age was $41.37 \pm 8.71$ years.
Age group categorization revealed that $72.78 \%$ of the workers were between 30 and 50 years of age. Of the 147 workers, most were married (76.87\%) and had completed high school (80.27\%). Most workers were classified as overweight (48.97\%). The mean duration of occupational exposure to dust was $12.26 \pm 7.09$ years, and $61.20 \%$ of the workers were nonsmokers (Table 1).

Respiratory symptoms were reported by 33 workers $(22.44 \%)$, some of whom reported more than one symptom; it is of note that, of those who were classified as symptomatic, 20 (35.08\%) had a history of smoking or a history of former smoking (Table 2).

Evaluation of pulmonary function revealed that most workers ( $n=121 ; 82.31 \%$ ) had normal spirometry results (Table 3 ). Of the workers who had normal spirometry results, $44(36.4 \%)$ were smokers or former smokers. In addition, of the workers who were classified as having spirometric changes, 13 (22.8\%) had a history of smoking or a history of former smoking.

Figure 1 shows the scatter plots of the correlation between spirometry results and duration of working in mining for nonsmokers (Figures $A$ ) and for smokers and former smokers (Figures B). In both cases, the variables analyzed were found to correlate poorly.

As for the association between respiratory symptoms and spirometric indices in the study participants, no significant values were observed (Table 4).

Table 1. General characteristics of the sample $(N=147)$.

\begin{tabular}{|c|c|c|c|c|}
\hline Characteristic & $\mathbf{n}$ & $\%$ & Mean \pm SD & Median \\
\hline Age group, years & & & $41.37 \pm 8.71$ & 42 \\
\hline$<30$ & 9 & 6.12 & & \\
\hline $30-50$ & 107 & 72.78 & & \\
\hline$>50$ & 31 & 21.10 & & \\
\hline $\mathrm{BMI}, \mathrm{kg} / \mathrm{m}^{2}$ & & & $27.83 \pm 3.83$ & 27 \\
\hline Normal weight & 33 & 22.44 & & \\
\hline Overweight & 72 & 48.97 & & \\
\hline Obesity & 42 & 28.59 & & \\
\hline Class I & 35 & 83.33 & & \\
\hline Class II & 6 & 14.28 & & \\
\hline Class III & 1 & 2.39 & & \\
\hline Duration of mining exposure, years & & & $12.26 \pm 7.09$ & 11 \\
\hline$<10$ & 88 & 59.86 & & \\
\hline $10-20$ & 57 & 38.77 & & \\
\hline$>20$ & 2 & 1.36 & & \\
\hline \multicolumn{5}{|l|}{ Smoking status } \\
\hline Nonsmoker & 90 & 61.20 & & \\
\hline Former smoker & 35 & 23.80 & & \\
\hline Smoker & 22 & 15.00 & & \\
\hline Smoking history, pack-years & & & $23.67 \pm 17.32$ & 20 \\
\hline \multicolumn{5}{|l|}{ Pulmonary function test } \\
\hline FVC, $\%$ of predicted & & & $94.17 \pm 14.45$ & 91 \\
\hline $\mathrm{FEV}_{1}, \%$ of predicted & & & $95.24 \pm 15.17$ & 93 \\
\hline $\mathrm{FEV}_{1} / \mathrm{FVC}, \%$ of predicted & & & $98.63 \pm 7.18$ & 100 \\
\hline $\mathrm{FEF}_{25-75 \%}, \%$ of predicted & & & $101.26 \pm 28.60$ & 97 \\
\hline
\end{tabular}

BMI: body mass index. 


\section{DISCUSSION}

The respiratory symptom results found for the workers classified as symptomatic $(22.4 \%)$ on the basis of the respiratory changes (cough, phlegm, wheezing, and dyspnea) in the present study do not corroborate the findings of a study in which a similar respiratory symptom questionnaire was used and $78 \%$ of the workers interviewed were found to have respiratory symptoms, $35 \%$ of whom had severe respiratory symptoms. ${ }^{(13)}$ The difference between the findings may be due to the different mining activities the workers were engaged in and the mineral dust types they were exposed to, since silica is more aggressive than pyrochlore. A similar study showed that the most common symptoms, in order of frequency, were phlegm $(41.7 \%)$, wheezing $(33.0 \%)$, cough $(31.9 \%)$, and dyspnea $(9.7 \%)^{(20)}$; in the present study, the results were similar, but the percentages were lower. Phlegm has also been found to be the most prevalent respiratory symptom in coal miners (36.4\%). ${ }^{(21)}$ The presence of respiratory symptoms may be associated with severity of disease and indicate cause for ongoing concern about the health status of workers. ${ }^{(22)}$ However, the present study shows that the most common symptoms were phlegm and wheezing (in $10.2 \%$ of the sample for both); these rates do not suggest significant disease on the basis of the respiratory changes, as has been observed in studies of occupational disease. ${ }^{(20,23)}$ The low frequency of respiratory symptoms in the present study can be explained by the specificity of the extracted mineral (pyrochlore) and by the institutional adoption of preventive measures, such as the Respiratory Protection Program, which includes several measures, from monitoring of dust levels to full provision of PPE to all workers and control regarding PPE use. Although the MRCQ has been used in other studies and investigations, it is important to emphasize that we found no studies describing the process of translation and validation of this instrument, and this should be considered a limiting factor of the present study.

In the present study, we found that $15 \%$ of the workers were smokers and $23.8 \%$ were former smokers. Tobacco smoking is considered the greatest single avoidable cause of morbidity and mortality worldwide. ${ }^{(23)}$ The relative importance of smoking in the respiratory health of occupational groups has previously been analyzed, with it being found that, in coal miners, the contribution of smoking to respiratory morbidity and mortality was more important than was occupational exposure, and that, in cases of exposure to silica or asbestos, the effects of those minerals on pulmonary function were similar in magnitude. ${ }^{(24)}$ For occupational respiratory diseases, this cause-and-effect interaction seems unquestionable; tobacco smoking is the major confounding bias that should be taken into account in the analysis of the risk factor involved in the genesis of respiratory symptoms. ${ }^{(23)}$ Smoking cessation leads to regression of bronchitic symptoms and to a trend toward a delayed decline in pulmonary function. ${ }^{(25)}$ Little is known about the effects of occupational exposure cessation on symptoms and on pulmonary function; however, on the basis of knowledge of pathogenesis, it is assumed that the effects of occupational exposure cessation on symptoms are similar to those of smoking cessation. (23)

The proportion of workers with normal spirometry results in the present study $(82.3 \%)$ is consistent with that reported in a study of a group of workers involved in the production of fertilizers and exposed to different occupational products, conducted in the state of Rio Grande do Sul, Brazil, (26) as well as with that reported in studies in the area of occupational lung diseases. ${ }^{(21,23)}$ A study conducted in the coal region in southernmost Santa Catarina, Brazil, found that most coal miners had normal spirometry results. Those findings were attributed to improvements in working conditions, to the use of PPE, and to the adoption of dust reduction measures in the workplace. ${ }^{(7)}$

The lack of correlation between spirometric variables and duration of mining exposure is consistent with reports from other studies that also found no significant differences between duration of occupational exposure to dust and pulmonary function. ${ }^{(23,27)}$ The findings are similar to those of a study of phosphate rock miners in Canada in which no reductions due to that occupational exposure were observed in the spirometric indices. ${ }^{(28)}$ The workers studied had serial annual spirometry over 3 to 7 years, and no evidence was found of a sharp decline in $\mathrm{FEV}_{1}$ that could be attributed to the occupational exposure. (28) In contrast, a recently published study showed a correlation between duration of exposure to air pollutants that are present in the ceramics production process and pulmonary function abnormalities; however, such a correlation was found for workers who did not use PPE. (29)

In the present study, no significant associations were observed between respiratory symptoms and

Table 2. Worker distribution by respiratory symptom and smoking status $(\mathrm{N}=147){ }^{\mathrm{a}}$

\begin{tabular}{lcc} 
Symptom & $\begin{array}{c}\text { Smokers/former } \\
\text { smokers }\end{array}$ & Nonsmokers \\
(n $=\mathbf{5 7} ; \mathbf{3 8 . 8} \%)$ & (n= 90; 61.2\%) \\
Cough & $5(8.77)$ & $7(7.77)$ \\
Phlegm & $9(15.78)$ & $6(6.66)$ \\
Wheezing & $5(8.77)$ & $10(11.11)$ \\
Dyspnea & $1(5.75)$ & $2(2.22)$ \\
\hline
\end{tabular}

aalues expressed as $\mathrm{n}(\%)$.

Table 3. Worker distribution by spirometric classification and smoking status $(\mathrm{N}=147)$. ${ }^{\text {a }}$

\begin{tabular}{lccc}
$\begin{array}{c}\text { Classification } \\
\text { (pattern) }\end{array}$ & Overall & $\begin{array}{c}\text { Smokers/ } \\
\text { former } \\
\text { smokers }\end{array}$ & Nonsmokers \\
Normal & $121(82.31)$ & $44(36.4)$ & $77(63.6)$ \\
Obstructive & $13(8.84)$ & $6(46.2)$ & $7(53.8)$ \\
Restrictive & $12(8.17)$ & $6(50.0)$ & $6(50.0)$ \\
Mixed & $1(0.68)$ & $1(100.0)$ & $0(0.0)$ \\
\hline
\end{tabular}

aValues expressed as $\mathrm{n}(\%)$. 

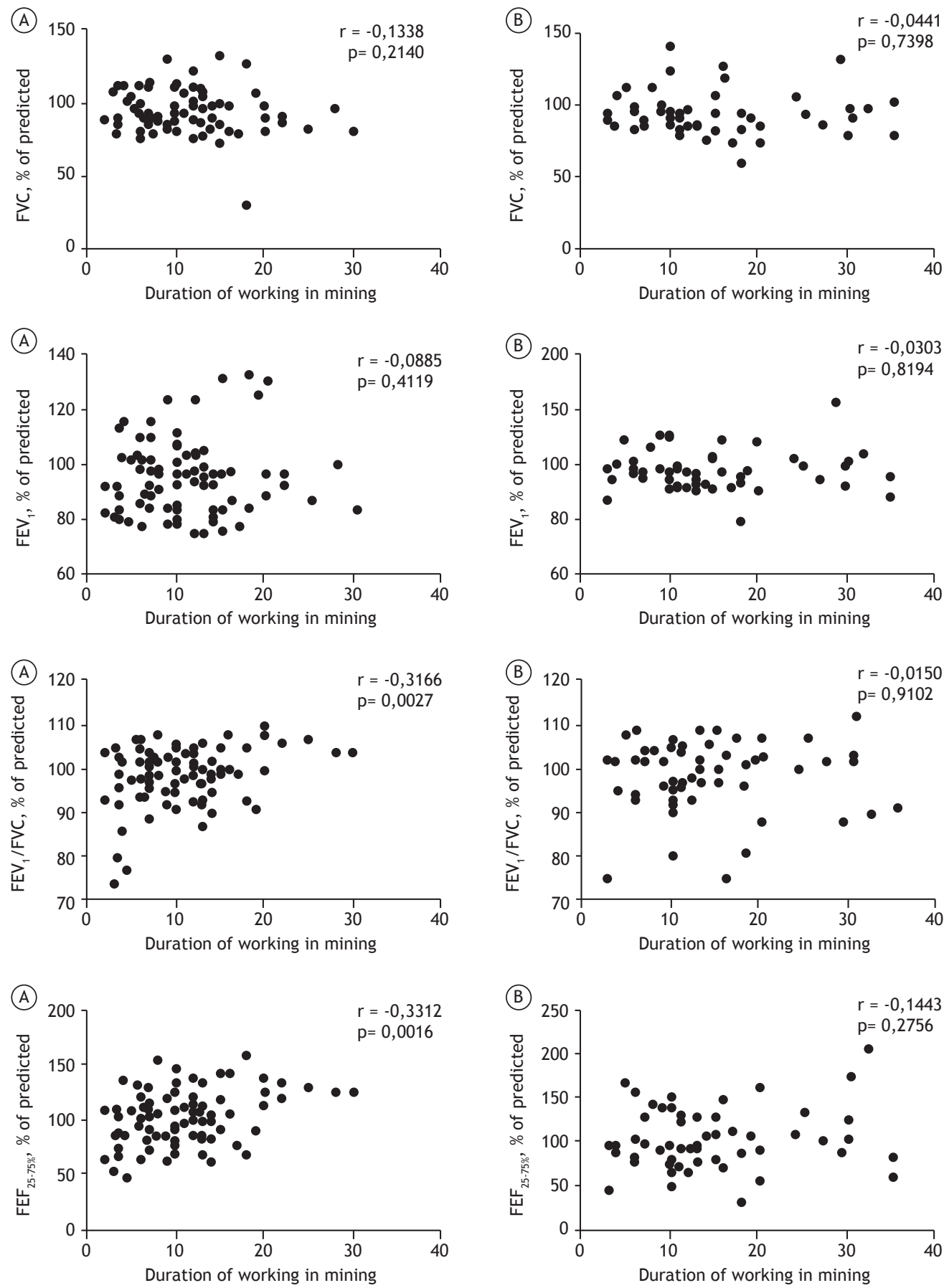

Figure 1. Scatter plots of the correlation between spirometry results and duration of working in mining for nonsmokers (in A) and for smokers and former smokers (in B).

spirometric changes, similar to what was reported by De Capitani in his study of workers exposed to phosphate rock. ${ }^{(30)}$ In contrast, in marble workers, a statistically significant difference has been found between dyspnea and spirometry results. ${ }^{(23)}$ In another study, symptoms were associated only with a history of respiratory disease and with smoking. ${ }^{(20)}$ It is important to point out that the findings of the present study were compared with those of studies involving workers exposed to other mineral dusts with potentially different effects. In addition, chest $\mathrm{X}$-rays were not performed in the present study, which makes it impossible to confirm the presence of pneumoconiosis. Company information indicates that, to date, there have been no recorded cases of pneumoconiosis in the workers exposed to mineral dust. 
Table 4. Association between respiratory symptoms and spirometry results $(\mathrm{N}=147){ }^{\text {a }}$

\begin{tabular}{lccc}
$\begin{array}{c}\text { Respiratory } \\
\text { symptoms }\end{array}$ & \multicolumn{2}{c}{ Spirometry results } & p \\
Normal & Abnormal & \\
Cough & & & $0.446^{*}$ \\
No & 112 & 23 & \\
Yes & 9 & 3 & \\
Total & 121 & 26 & $0.306^{*}$ \\
Phlegm & & & \\
No & 110 & 22 & \\
Yes & 11 & 4 & $0.144^{*}$ \\
Total & 117 & 26 & \\
Wheezing & & & \\
No & 111 & 21 & \\
Yes & 10 & 5 & $0.470^{* *}$ \\
Total & 121 & 26 & \\
Dyspnea & & 16 & \\
No & 86 & 10 & \\
Yes & 35 & 26 & \\
Total & 121 &
\end{tabular}

avalues expressed as $\mathrm{n}$. *Fisher's exact test. $* *$ Chisquare test.
It is well known how important it is to adopt measures for promoting worker health in the processes of improvement of quality of life, functionality, and productivity, whether on an occupational or personal level. These assumptions were confirmed in the present study, since the company has worker-targeted care programs that are based on ongoing activities to continuously monitor the workers and the workplace, encouragement of good health practices, and regular follow-ups with specialists.

This study presents itself as an important guide to evaluating pulmonary function in workers involved in pyrochlore extraction activities, given that there are few studies in the literature evaluating possible respiratory diseases in workers with this type of exposure. It is possible that the low frequency of respiratory symptoms and spirometric changes in the pyrochlore miners, the poor correlation between respiratory symptoms and spirometry results, and the poor correlation between respiratory symptoms and duration of exposure to dust indicate good working conditions and the prevention of diseases in this sector, combined with the low toxicity of pyrochlore.

\section{REFERENCES}

1. Plumlee GS, Morman SA. Mine Wastes and Human Health. Elements. 2011;7(6):399-404. http://dx.doi.org/10.2113/gselements.7.6.399

2. Fernandes $A L$, Stelmach $R$, Algranti E. Occupacional asthma [Article in Portuguese]. J Bras Pneumol. 2006;32(Suppl 1):S27-S34. http:// dx.doi.org/10.1590/S1806-37132006000800006

3. Ross $\mathrm{MH}$, Murray J. Occupational respiratory disease in mining Occup Med (Lond). 2004;54(5):304-10. http://dx.doi.org/10.1093/ occmed/kgh073

4. Brasil. Ministério da Saúde. Secretaria de Atenção à Saúde Departamento de Ações Programáticas Estratégicas. Saúde do trabalhador, protocolos de complexidade diferenciada. Série A Brasília: Ministério da Saúde; 2006.

5. Souza Filho AJ, Alice SH, Luca V. Pneumoconiosis of coal mine workers [Article in Portuguese]. J Pneumol. 1981;7(2):57-66.

6. de Capitani EM, Algranti E. Other pneumoconioses [Article in Portuguese]. J Bras Pneumol. 2006;32(Suppl 2):S54-S59. http:// dx.doi.org/10.1590/S1806-37132006000800010

7. Souza FJ, Gallas MG, Souza Filho AJ. Documental analysis of the epidemiological profile of a group of coal miners in the southernmost region of Santa Catarina in 2006 [Article in Portuguese. Arq Catarin Med. 2013;42(4):73-8.

8. Instituto Brasileiro de Mineração - IBRAM [homepage na Internet] Brasília: IBRAM [cited 2014 Oct 17]. Informações sobre a Economia Mineral do Estado de Minas Gerais. [Adobe Acrobat document, 14p.]. Available from: http://www.ibram.org.br/sites/1300/1382/00004355 pdf

9. Wall F, Williams CT, Wooley AR. Pyrochlore from weathered carbonatite at Lueshe, Zaire. Mineralog Mag. 1996;60:731-50. http:// dx.doi.org/10.1180/minmag.1996.060.402.03

10. Beynon H. Protesto Ambiental e Mudança Social no Reino Unido. Mana. 1999:5(1):7-28. http://dx.doi.org/10.1590/S0104 93131999000100001

11. Bagatin E, Pereira CA, Afiune JB. Granulomatous diseases of occupational etiology [Article in Portuguese]. J Bras Pneumol. 2006;32(Suppl 1):S69-S84. http://dx.doi.org/10.1590/S180637132006000800012

12. Dias da Cunha K, Lipztein JL, Azeredo AM, Melo D, Julião LM, Lamego FF, et al. Study of workers exposure to thorium, uranium and niobium mineral dust. Water Air Soil Pollut. 2002;137(1):45-61. http://dx.doi.org/10.1023/A:1015599406550

13. Rondon EN, Silva RM, Botelho C. Respiratory symptoms as health status indicators in workers at ceramics manufacturing facilities. $J$
Bras Pneumol. 2011:37(1):36-45. http://dx.doi.org/10.1590/S1806 37132011000100007

14. Lung function testing: selection of reference values and interpretative strategies. American Thoracic Society. Am Rev Respir Dis. 1991;144(5):1202-18. http://dx.doi.org/10.1164/ajrccm/144.5.1202

15. Pereira CA. Espirometria. J Pneumol. 2002;28(Suppl 3):S1-S82.

16. Pereira CA. I Consenso Brasileiro sobre Espirometria. J Pneumol. 1996:22(3):105-64

17. Pereira CA, Barreto SP, Simões JG, Pereira FW, Gerstler JG, Nakatan J. Valores de Referência para Espirometria em uma amostra da população brasileira adulta. J Pneumol. 1992;18(1):10-22.

18. Associação Brasileira para o Estudo da Obesidade e da Síndrome Metabólica (ABESO). Diretrizes brasileiras de obesidade 2009/2010. 3rd ed, Itapevi: AC Farmacêutica; 2009.

19. Almeida TA, Wiermann AL, Wiermann AL, Camargo JF, Johnsson RR, Martinelli FA, et al. Análise retrospectiva epidemiológica e de resultados de tratamento de pacientes portadores de câncer de pulmão metastático em instituição no Sul do Brasil. Rev Bras Oncol Clin. 2010:22(7):92-8

20. Lemle A, Araújo AJ, Lapa e Silva JR, Lima FP, Santiago AC, Cardoso $A P$, et al. Sintomas respiratórios e testes espirográficos dos funcionários de uma pedreira do Rio de Janeiro. Rev Assoc Med Bras. 1994:40(1):23-35

21. Algranti E. Métodos de investigação em doenças ocupacionais pulmonares. J Pneumol 1994;20:165-73.

22. Bagatin E, Jardim JR, Nery LE, Capitani EM, Marchi E, Sabino MO et al. Ocorrência de silicose pulmonar na região de Campinas - SP. J Pneumol. 1995;21(1):17-26.

23. Pivetta $A B$, Botelho $C$. Prevalência de sintomas respiratórios e avaliação espirométrica em trabalhadores de marmorarias. J Pneumol. 1997;23(4):179-88.

24. Elmes PC. Relative importance of cigarette smoking in occupational lung disease. $\mathrm{Br} J$ Ind Med. 1981;38(1):1-13. http://dx.doi. org/10.1136/oem.38.1.1

25. Dockery DW, Speizer FE, Ferris BJ Jr, Ware JH, Louis TA, Spiro A 3rd. Cumulative and reversible effects of lifetime smoking on simple tests of lung function in adults. Am Rev Respir Dis. 1988;137(2):28692. http://dx.doi.org/10.1164/ajrccm/137.2.286

26. Hüttner MD, Moreira JS. Environmental and epidemiologica evaluation of workers of the fertilizer industry of Rio Grande, RS [Article in Portuguese]. J Pneumol. 2000;26(5):245-53. http://dx.doi. 
org/10.1590/S0102-35862000000500005

27. Hertzberg VS, Rosenman KD, Reilly MJ, Rice CH. Effect of occupational silica exposure on pulmonary function. Chest. 2002;122(2):721-8. http://dx.doi.org/10.1378/chest.122.2.721

28. Dutton CB, Pigeon MJ, Renzi PM, Feustel PJ, Dutton RE, Renzi GD. Lung function in workers refining phosphorus rock to obtain elementary phosphorus. J Occup Med. 1993;35(10):1028-33.
29. Salicio VA, Botelho C, Silva AM, Salicio MA. Factors associated with alterations in lung function among workers in the ceramics industry [Article in Portuguese]. Cienc Saude Colet. 2013;18(5):1353-60. http://dx.doi.org/10.1590/S1413-81232013000500020

30. De Capitani EM. Prevalence of pneumoconiosis among workers exposed to phosphate rock. Rev Saude Publica. 1989;23(2):98-106. http://dx.doi.org/10.1590/S0034-89101989000200003 